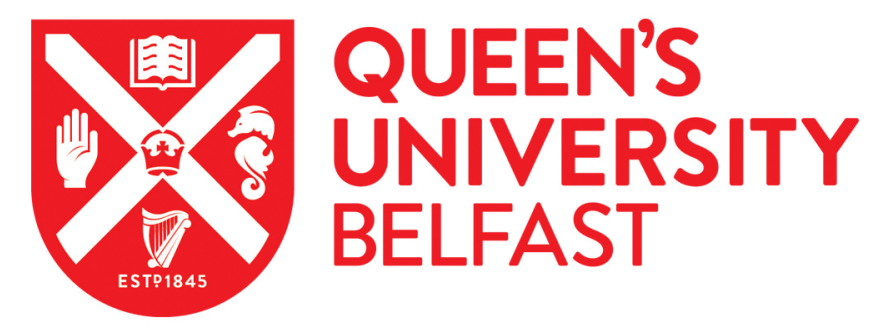

\title{
Changes in the soil environment from excessive application of fertilizers and manures to two contrasting intensive cropping systems on the North China Plain
}

Ju, X. T., Kou, C. L., Christie, P., Dou, Z. X., \& Zhang, F. S. (2007). Changes in the soil environment from excessive application of fertilizers and manures to two contrasting intensive cropping systems on the North China Plain. Environmental Pollution, 145(2), 497-506. https://doi.org/10.1016/j.envpol.2006.04.017

\section{Published in:}

Environmental Pollution

Queen's University Belfast - Research Portal:

Link to publication record in Queen's University Belfast Research Portal

\section{General rights}

Copyright for the publications made accessible via the Queen's University Belfast Research Portal is retained by the author(s) and / or other copyright owners and it is a condition of accessing these publications that users recognise and abide by the legal requirements associated with these rights.

Take down policy

The Research Portal is Queen's institutional repository that provides access to Queen's research output. Every effort has been made to ensure that content in the Research Portal does not infringe any person's rights, or applicable UK laws. If you discover content in the Research Portal that you believe breaches copyright or violates any law, please contact openaccess@qub.ac.uk. 


\title{
Changes in the soil environment from excessive application of fertilizers and manures to two contrasting intensive cropping systems on the North China Plain
}

\author{
X.T. Ju ${ }^{\text {a,*}}{ }^{\text {, C.L. Kou }}{ }^{\text {a,b }}$, P. Christie ${ }^{\text {a,c }}$, Z.X. Dou ${ }^{\text {d }}$, F.S. Zhang ${ }^{\text {a }}$ \\ ${ }^{a}$ Key Laboratory of Plant-Soil Interactions, Ministry of Education; College of Agricultural Resources and Environmental Sciences, \\ China Agricultural University, Beijing 100094, China \\ ${ }^{\mathrm{b}}$ Institute of Soil and Fertilization, Henan Academy of Agricultural Sciences, Zhengzhou, 450002, China \\ ${ }^{\mathrm{c}}$ Agricultural and Environmental Science Department, Queen's University Belfast, Newforge Lane, Belfast BT9 5PX, UK \\ ${ }^{\mathrm{d}}$ Center for Animal Health and Productivity, Department of Clinical Studies, School of Veterinary Medicine, University of Pennsylvania, \\ 382 West Street Road, Kennett Square, PA 19348, USA
}

Received 2 December 2005; received in revised form 19 April 2006; accepted 20 April 2006

Extremely high nutrient inputs to intensively managed vegetable crops in northeast China may lead to very serious degradation of soil and water quality.

\begin{abstract}
Effects of excessive fertilizer and manure applications on the soil environment were compared in greenhouse vegetable systems shifted from wheat-maize rotations 5-15 years previously and in wheat-maize rotations. N, P and K surpluses to the greenhouses were 4328,1337 and $1466 \mathrm{~kg} \mathrm{ha}^{-1}$ year $^{-1}$, respectively compared to 346,65 and $-163 \mathrm{~kg} \mathrm{ha}^{-1}$ year $^{-1}$ to wheat-maize fields. Subsequently, substantial mineral $\mathrm{N}$ and available $\mathrm{P}$ and $\mathrm{K}$ accumulated in the soil and leaching occurred down the soil profile in the greenhouses. Soil pH under vegetables was significantly lower than in the wheat-maize fields, while the EC was significantly higher in the vegetable soils. The mean Cd concentration in the vegetable soils was 2.8 times that in the wheat-maize rotations. Due to excessive fertilizer application in greenhouse vegetable production in northeast China, excessive salt and nitrate concentrations may accumulate and soil quality may deteriorate faster than in conventional wheat-maize rotations.
\end{abstract}

(C) 2006 Elsevier Ltd. All rights reserved.

Keywords: Greenhouse vegetables; Wheat-maize rotation; Nitrogen; Phosphorus; Potassium; Electrical conductivity; Soil pH; Trace elements; Heavy metals

\section{Introduction}

Mineral fertilizer consumption in Chinese agriculture has increased greatly over the last three decades but has decreased in northwest Europe over the same period (Richter and Roelcke, 2000; Ju et al., 2004a). At present, overuse or misuse of fertilizers in agriculture in northeast China contributes to

\footnotetext{
* Corresponding author. Tel.: +86106273 3459; fax: +861062731016. E-mail address: juxt@cau.edu.cn (X.T. Ju).
}

environmental damage from non-point source pollution (Zhang et al., 2004; Jin et al., 2005) and is therefore of great concern nationally and internationally. Fertilizer application rates in intensive agricultural systems have increased dramatically in recent years on the North China Plain, especially in greenhouse vegetable production systems (Ju et al., 2005). Because of the relatively high economic value of the extra yields and difficulties in the accurate management of water and nutrient supply in these systems, farmers use very large amounts of fertilizers and irrigation water to obtain maximum yields. For example, fertilizer $\mathrm{N}$ is often applied at rates 
$>1200 \mathrm{~kg} \mathrm{~N} \mathrm{ha}^{-1}$ and irrigation water at $1000 \mathrm{~mm}$ per crop, and two or three crops are grown each year in one of the most important vegetable production areas, Shouguang, Shandong province (Zhu et al., 2005). These high fertilizer inputs and the extremely low crop recoveries of fertilizer nutrients (usually $<10 \%$ in the case of $\mathrm{N}$ ) lead to marked deterioration in soil and groundwater quality and the systems are clearly unsustainable (Zhang et al., 1996; Li et al., 2001; Dou, 2005; Zhu et al., 2005).

Although similar problems were faced from the 1960s to the 1980s in western European countries (Richter and Roelcke, 2000; Van Eerdt et al., 2005), their magnitude was lower than the current Chinese problem. For instance, an application rate of fertilizer $\mathrm{N}$ of $200 \mathrm{~kg} \mathrm{ha}^{-1}$ for one cereal crop would have been regarded as high in western Europe but the rate currently used by most farmers in northeast China exceeds $300 \mathrm{~kg} \mathrm{~N} \mathrm{ha}^{-1}$ per crop and there may be two or three crops in one year. In vegetable production systems the fertilizer $\mathrm{N}$ application rate in western Europe would have seldom matched the rate of $2800 \mathrm{~kg} \mathrm{~N}^{-1}$ used in greenhouse systems by some farmers in northeast China (Ju et al., 2004a). Chinese greenhouse vegetable production systems thus provide an excellent opportunity for studying the effects of extremely high fertilizer inputs on degradation of soil and water quality.

Soil quality can be defined as the capacity of the soil to function within ecosystem and land use boundaries, to sustain biological productivity, maintain environmental quality and promote plant, animal and human health (Doran et al., 1996). Soil chemical and biological properties in greenhouse vegetable production may change dramatically after several years of continually high inputs of fertilizers and irrigation water and planting of shallow rooting vegetable crops compared with open field cereal production systems. Soil OM, alkalihydrolyzable $\mathrm{N}$, and available $\mathrm{P}$ and $\mathrm{K}$ have been observed to accumulate significantly in vegetable greenhouses (Gao et al., 2000). Because farmers prefer to apply high-P fertilizers such as diammonium phosphate or 15-15-15 compound fertilizers to vegetable crops in north China, high concentrations of $\mathrm{P}$ and imbalances of $\mathrm{N}, \mathrm{P}$ and $\mathrm{K}$ often occur in the intensively managed soils.

Changes in soil water balance resulting from a lack of leaching by rainfall and strong evaporation of soil water due to long-term cover together with high fertilizer application rates may lead to increasing salinity in the surface soils of the plastic film greenhouses in which vegetables are grown (Wu et al., 2000). The main anion present is $\mathrm{NO}_{3}^{-}(67-76 \%$ of total anions) in soil salinity in these systems (Xue et al., 1994) and $\mathrm{NO}_{3}^{-}$content was found to be significantly correlated with total soil salinity (Liang et al., 1997). Secondary salinization in the greenhouse soils is characterized by accumulation of $\mathrm{NO}_{3}^{-}$, a contrasting situation compared with saline soils in open fields of coastal and inland areas. Soil salinization increases the osmotic potential of the soil solution, leading to water stress and ion antagonism in the crops (Greenway and Munns, 1980). Total soil salinity content and $\mathrm{NO}_{3}^{-}$ content showed significant correlations with soil EC (Xue et al., 1994). Thus, soil EC may be used as an index of salt accumulation or $\mathrm{NO}_{3}^{-}$accumulation under these conditions. The tolerance limit of most crops is an $\mathrm{EC}$ of $0.4 \mathrm{~S} \mathrm{~m}^{-1}$ (Kingery et al., 1994). Some studies have shown soil EC values up to $0.4 \mathrm{~S} \mathrm{~m}^{-1}$ in greenhouses after 8 years of intensive vegetable cropping (Wu et al., 2000; Li et al., 2001).

Long-term application of large amounts of fertilizers and manures may lead to soil acidification in vegetable greenhouses. Numerous studies have shown decreasing soil $\mathrm{pH}$ with increasing number of cropping years (Meng et al., 2000; Zhao et al., 2000). After 13 years of greenhouse vegetable production in Shouguang, Shandong province, the soil $\mathrm{pH}$ declined to 4.3 in some cases, with potential detrimental effects on crop yield and quality in these systems ( $\mathrm{Li}, 2001)$. Changes in soil $\mathrm{pH}$ may affect nutrient availability, and in calcareous soils a decrease in soil $\mathrm{pH}$ may increase the availability of elements such as $\mathrm{P}, \mathrm{Fe}, \mathrm{Mn}, \mathrm{Cu}$, and $\mathrm{Zn}$, but extremely low soil $\mathrm{pH}$ values could have direct detrimental effects on plant growth. Exchangeable $\mathrm{Ca}$ and $\mathrm{Mg}$ in vegetable greenhouse soils were lower than in open fields, but available $\mathrm{Cu}$, $\mathrm{Fe}, \mathrm{Mn}$, and Zn showed the opposite trend (Xiao et al., 1997).

Few studies have examined heavy metals in vegetable greenhouse soils. Many phosphate rocks contain heavy metals such as $\mathrm{Pb}$ and $\mathrm{Cd}$ and large application rates of $\mathrm{P}$ fertilizer may not only increase soil $\mathrm{P}$ but also lead to accumulation of the metals above the maximum limit values (Sharpley and Menzel, 1987; Song et al., 1996; Powlson, 1997). Jinadasa et al. (1997) found that $\mathrm{Cd}$ concentrations in vegetables could exceed the limit value if the soil $\mathrm{Cd}$ concentration reached $0.3 \mathrm{mg} \mathrm{Cd} \mathrm{kg}{ }^{-1}$.

Clearly, systematic studies on the impacts of different cropping systems (i.e. different management practices) on soil properties are needed for the proper development of sustainable high yielding vegetable systems in relation to environmental quality. The objectives of the present study were to investigate soil nutrients and heavy metal accumulation and changes in soil $\mathrm{pH}$ and $\mathrm{EC}$ in vegetable greenhouses and to compare these with fields used for cereal rotations. We took wheat-maize fields as a reference because the vegetable greenhouses were established on areas formerly used to grow wheat-maize rotations. This may allow comparison between conditions on areas that changed to greenhouse vegetable production with surrounding areas that have remained under wheat-maize rotations.

\section{Materials and methods}

\subsection{Site description and cropping systems}

The study site at Huimin county is located on the north shore of the lower reaches of the Yellow River in the northeast of Shandong province on an alluvial plain at $37^{\circ} 6^{\prime}-37^{\circ} 36^{\prime} \mathrm{N}, 117^{\circ} 16^{\prime}-117^{\circ} 49^{\prime} \mathrm{E}$. There is an area of flat agricultural land of 73,480 ha with a mean altitude of $12.8 \mathrm{~m}$ and a gradient of 1:6000 at the ground surface. Annual average precipitation was $578 \mathrm{~mm}$ for the period 1971 to 2000 , of which $61-84 \%$ occurred between June and August, and is typical of the warm-temperate sub-humid continental monsoon climate. The main soil type is loamy silty alluvial soil (FAO system). The main crops grown are wheat, maize, greenhouse vegetables, cotton (Gossypium hirsutum L.), and fruit trees. Zijiao township, one of the most important vegetable 
production areas in the county, was selected as a representative area for investigation.

One of the planting patterns in the greenhouse vegetable cropping system consisted of transplanting cucumber (Cucumis sativus L.) in October and final harvest in June of the following year, then a fallow period until October. Another pattern was sowing of celery (Apium graveolens L.) in October and final harvest in January of the following year, then growing tomato (Lycopersicon esculentum Mill.) from February to July, and then a fallow period until October. During this annual rotation, more than 13 irrigation events and seven split applications of fertilizer were applied in conventional farming practice. In the wheat-maize double cropping system winter wheat was grown from October to June of the following year and summer maize was grown from the middle of June to the end of September. Two applications of fertilizer, one basal application before sowing and one topdressing in the middle growth stages, were made to both crops combined with irrigation.

\subsection{Soil and manure sampling}

A multistage sampling technique was used to select representative fields for sampling soils from each cropping system. Firstly, we randomly selected three villages from a total of 68 villages in Zijiao township. Secondly, ten fields were randomly selected in each selected village for sampling soils from vegetable greenhouses. A total of 30 vegetable greenhouses were randomly selected in Zijiao township, and an adjacent wheat-maize field was also selected to serve as a comparison with each greenhouse. The land had been used to grow wheat-maize rotations before the greenhouses were established 5-15 years before the study commenced. Soil samples were taken from all the selected greenhouses and fields over the period 18-29 June, 2002 and after the crops were harvested. Samples were collected from the top $90 \mathrm{~cm}$ of the soil profile at five sites (following a serpentine pattern in each field) at 30$\mathrm{cm}$ intervals in each vegetable greenhouse and cereal field. Samples from the five sites in each field were mixed thoroughly to obtain composite samples from each depth layer $(0-30,30-60$ and $60-90 \mathrm{~cm})$, placed in labeled plastic bags, sealed and stored in ice boxes before analysis for $\mathrm{NH}_{4}^{+}-\mathrm{N}$ and $\mathrm{NO}_{3}^{-}-\mathrm{N}$ in the laboratory.

The main types of organic manure used by local farmers are cattle, pig and chicken manures, hemp seed cake, bean cake and cottonseed cake. Samples of these manures were collected when farmers were applying them in the field from October 2001 to September 2002. Samples of about $1 \mathrm{~kg}$ were collected from 10-15 points within each manure heap. They were placed on clean plastic boards, broken up and mixed thoroughly and a sub-sample of about $0.5 \mathrm{~kg}$ was obtained using the quartering procedure. Part of this sub-sample was used to determine water content and the remainder was air-dried for nutrient analysis.

\subsection{Sample analysis}

Fresh soil samples were divided into two sub-samples after sieving to $<5 \mathrm{~mm}$, one of which was used to determine soil mineral nitrogen $\left(\mathrm{NO}_{3}^{-}-\mathrm{N}\right.$ and $\mathrm{NH}_{4}^{+}-\mathrm{N}$ ) and the other was air-dried for analysis of soil $\mathrm{pH}, \mathrm{EC}, \mathrm{OM}$, $\mathrm{TN}$, available $\mathrm{P}$ and $\mathrm{K}$, available $\mathrm{Zn}, \mathrm{Mn}, \mathrm{Fe}, \mathrm{Cu}$ and the additional heavy metals $\mathrm{Pb}$ and $\mathrm{Cd}$. Each fresh soil sub-sample was extracted with $0.01 \mathrm{~mol} \mathrm{~L}^{-1}$ $\mathrm{CaCl}_{2}$ to determine the concentrations of $\mathrm{NH}_{4}^{+}-\mathrm{N}$ and $\mathrm{NO}_{3}^{-}-\mathrm{N}$ using a continuous flow analyzer (TRAACS 2000, Bran and Luebbe, Norderstedt, Germany). Soil OM was measured by dichromate digestion, TN by the Kjeldahl method, soil $\mathrm{pH}$ in water with a 1:2.5 soil-to-water ratio, soil EC by a 1:5 soil-to-water ratio as described by Rhoades (1996), available $\mathrm{P}$ (Olsen-P) by extraction with $0.5 \mathrm{~mol} \mathrm{~L}^{-1} \mathrm{NaHCO}_{3}$, available $\mathrm{K}$ by extraction with $1 \mathrm{~mol} \mathrm{~L}^{-1} \mathrm{NH}_{4} \mathrm{OAC}$, and microelements and heavy metals by the DTPA extraction-ICP method (Optima 3300 DV, Perkin Elmer, USA). Total N, P, and K in manure were measured according to the methods of Che and $\mathrm{He}$ (1999).

\subsection{Calculation of nutrient inputs and balance}

Detailed records were made of farmers' management practices in each field from October 2001 to September 2002 and it was established that the management history of each field was similar to that practiced during the year of our survey. Background data collected included the area of the field or greenhouse plot, the age of the greenhouse, and the types and amounts of fertilizers applied. N, P and $\mathrm{K}$ inputs from fertilizers were calculated from the amounts of fertilizers applied and the forms and concentrations of nutrients present. The main fertilizers used in the study fields were urea, ammonium bicarbonate, diammonium phosphate, compound or mixed fertilizers and calcium mono-phosphate. $\mathrm{N}, \mathrm{P}$ and $\mathrm{K}$ inputs from organic manures were also estimated by analysis of representative samples and the application rates used. The nutrients remove by aboveground plant parts were calculated from nutrient concentrations and aboveground biomass. The nutrient balance was calculated by subtracting aboveground nutrient removal from fertilizer input (mineral + manure).

\subsection{Statistical analysis}

The primary data were manipulated using Microsoft Excel spreadsheets. The significance of fertilizers, soil nutrient accumulation, soil $\mathrm{pH}, \mathrm{EC}$, micronutrients and heavy metals comparing the two cropping systems were analyzed by $t$-test using the SAS software package (Version 6.12, 1997; SAS Institute Inc., Cary, NC, USA). The regressions between soil $\mathrm{pH}, \mathrm{EC}$ and $\mathrm{NO}_{3}^{-}-\mathrm{N}$ concentrations were analyzed using PROC NLIN of the SAS software package.

\section{Results}

\subsection{Fertilizer and manure use and nutrient balance in the two cropping systems}

The annual N, P and $\mathrm{K}$ inputs from fertilizers and manures applied to the greenhouse vegetable systems were all significantly $(p<0.001)$ higher than those applied to the wheat- maize fields (Table 1). The rates of fertilizer N, P and $\mathrm{K}$ applied to greenhouse vegetables were 4.7, 10.1 and 23.4 times those applied to the cereal fields, and the corresponding data for manure nutrients were 33.0, 26.7 and 15.2, respectively. The fertilizer inputs within each cropping system were very variable among individual fields, reflecting the lack of a formal fertilizer recommendation system and weakness of the local extension service. The annual fertilizer N, P and $\mathrm{K}$ inputs in the vegetable greenhouses were much higher than the application rates recommended by the extension service (N 750-1030, P 180-300, K 225-375 kg ha $\left.{ }^{-1}\right)(\mathrm{He}$ et al., 2000). As for the wheat-maize rotations, the annual fertilizer $\mathrm{N}$ rate was also much higher than recommended (N 300-390 kg ha ${ }^{-1}$ ), but the annual fertilizer P rates were close to the range of recommended rates $\left(\mathrm{P} 80-90 \mathrm{~kg} \mathrm{ha}^{-1}\right)$, and less $\mathrm{K}$ was applied than was recommended (K 50-150 kg $\mathrm{ha}^{-1}$ ). Manures were applied to all of the greenhouses in our survey, but only to 20 of the 30 wheat fields during the wheat-growing season, and to none of the cereal fields during the maize growing season. The data indicate that most farmyard manure is used for vegetable production. Moreover, $\mathrm{K}$ fertilizer was applied to 27 of the 30 greenhouses, but to only 8 of the 30 cereal fields surveyed for wheat, and to 14 fields for maize. Available $\mathrm{K}$ in the top $30 \mathrm{~cm}$ of the soil profile in the 30 wheat-maize fields was much lower than recommended as sufficient $\left(>100 \mathrm{mg} \mathrm{kg}^{-1}\right.$, Fig. 2B), which might result from crop residuals not having been returned to the fields in most cases.

Very large surpluses of N, P and $\mathrm{K}$ were found in the greenhouse vegetable production system compared to the 
Table 1

Fertilizers and manures applied to two cropping systems in rotations in 2001-02

\begin{tabular}{|c|c|c|c|c|c|c|c|c|c|}
\hline \multirow[t]{2}{*}{ Cropping system } & \multirow{2}{*}{$\begin{array}{l}\text { No. of } \\
\text { sites }\end{array}$} & \multirow{2}{*}{$\begin{array}{l}\text { Descriptive } \\
\text { Statistics }\end{array}$} & \multirow{2}{*}{$\begin{array}{l}\text { Yield }^{\mathrm{a}} \\
\left(\mathrm{t} \mathrm{ha}^{-1} \text { year }^{-1}\right)\end{array}$} & \multicolumn{3}{|c|}{ Fertilizer $\left(\mathrm{kg} \mathrm{ha}^{-1}\right.$ year $\left.^{-1}\right)$} & \multicolumn{3}{|c|}{ Manure $\left(\mathrm{kg} \mathrm{ha}^{-1}\right.$ year $\left.^{-1}\right)$} \\
\hline & & & & $\mathrm{N}$ & $\mathrm{P}$ & $\mathrm{K}$ & $\mathrm{N}$ & $\mathrm{P}$ & $\mathrm{K}$ \\
\hline \multirow[t]{3}{*}{ Greenhouse vegetables } & \multirow[t]{3}{*}{30} & Mean & 87.0 & 2823 & 928 & 925 & 1847 & 481 & 991 \\
\hline & & Range & $7-171$ & $375-7344$ & $176-3252$ & $0-2655$ & $23-4775$ & $4-1380$ & $39-2794$ \\
\hline & & $\mathrm{CV}(\%)$ & 50.6 & 70 & 82 & 83 & 69 & 75 & 67 \\
\hline \multirow[t]{3}{*}{ Wheat-maize rotation } & \multirow[t]{3}{*}{30} & Mean & 11.3 & 606 & 92 & 38 & 56 & 18 & 65 \\
\hline & & Range & $8.3-13.5$ & $240-1099$ & $25-154$ & $0-137$ & $0-246$ & $0-80$ & $0-286$ \\
\hline & & $\mathrm{CV}(\%)$ & 12.4 & 30 & 39 & 99 & 159 & 159 & 159 \\
\hline Significance & & & & $* * * \mathrm{~b}$ & $* * *$ & $* * *$ & $* * *$ & $* * *$ & $* * *$ \\
\hline
\end{tabular}

a Vegetable yields expressed as annual fresh weight yield, and the yields of wheat and maize on air-dry basis.

b Significant differences $(p<0.001)$ between the two cropping systems.

wheat - maize rotation (Table 2 ). The $\mathrm{N}$ removed by the aboveground parts of vegetables was not significantly $(p>0.05)$ higher than by wheat-maize, but $\mathrm{P}$ and $\mathrm{K}$ were significantly higher $(p<0.05)$. The $\mathrm{N}$ and $\mathrm{P}$ surpluses were also high but $\mathrm{K}$ was in deficit in the wheat-maize rotation. The $\mathrm{K}$ balance could be achieved by returning crop residues to the fields in the wheat-maize rotation because these would remove up to $210-223 \mathrm{~kg} \mathrm{~K} \mathrm{ha}^{-1}$ in our investigation.

\subsection{Comparison between the two cropping systems in soil OM, TN and mineral $N$}

Soil $\mathrm{OM}$ and $\mathrm{TN}$ in the greenhouses were significantly ( 27.6 and $38.1 \%, p<0.001$ ) higher than in the wheat-maize fields (Table 3), and this may be largely due to application of large amounts of manure for vegetable production.

$\mathrm{NO}_{3}^{-}-\mathrm{N}$ accumulation in the top $90 \mathrm{~cm}$ of greenhouse soils was significantly $(p<0.001)$ higher than in wheat-maize fields (Fig. 1A). The ranges were $274-4219 \mathrm{~kg} \mathrm{~N} \mathrm{ha}^{-1}$ with $1390 \mathrm{~kg} \mathrm{Nha}^{-1}$ on average in the greenhouses, and 94-690 kg N ha ${ }^{-1}$ with $248 \mathrm{~kg} \mathrm{~N} \mathrm{ha}^{-1}$ on average in the wheat-maize fields. Although $\mathrm{NH}_{4}^{+}-\mathrm{N}$ accumulation in the top $90 \mathrm{~cm}$ of greenhouse soil profiles was significantly $(p<0.01$ or 0.001$)$ higher than in cereal fields (Fig. 1B), the difference between the two cropping systems was much smaller than the difference in $\mathrm{NO}_{3}^{-}-\mathrm{N}$. Average $\mathrm{NH}_{4}^{+}-\mathrm{N}$ accumulation at $0-90 \mathrm{~cm}$ soil depth in the greenhouses was $100.4 \mathrm{~kg} \mathrm{~N} \mathrm{ha}^{-1}$ compared with $56.6 \mathrm{~kg} \mathrm{~N} \mathrm{ha}^{-1}$ in the cereal fields.

Total soil accumulation of $\mathrm{NO}_{3}^{-}-\mathrm{N}(0-90 \mathrm{~cm})$ amounted to $91 \%$ of soil mineral $\mathrm{N}$ in the greenhouses, and to $79 \%$ in the cereal fields. This indicates that the soils had high potential for nitrification (Richter and Roelcke, 2000; Liu et al., 2003;
Ju et al., 2004a,b). Since $\mathrm{NO}_{3}^{-}-\mathrm{N}$ was the main fraction of mineral $\mathrm{N}$, differences in mineral $\mathrm{N}$ (Nmin) between the two cropping systems showed similar trends to $\mathrm{NO}_{3}^{-} \mathrm{N}$. Substantial accumulation of $\mathrm{NO}_{3}^{-}-\mathrm{N}$ in the deep subsoil reflected strong leaching processes in both cropping systems, but especially in vegetable production. However, we did not determine soil exchangeable $\mathrm{NH}_{4}^{+}-\mathrm{N}$ and we have therefore underestimated the total amount of potentially available soil ammonium nitrogen.

\subsection{Comparison between the two cropping systems in soil available $P$ and $K$}

Soil available $\mathrm{P}(0-90 \mathrm{~cm})$ in the greenhouses was significantly $(p<0.001)$ higher than in the wheat - maize fields (Fig. 2A), being $1321 \mathrm{~kg} \mathrm{Pha}^{-1}$ in the former and $158 \mathrm{~kg}$ $\mathrm{Pha}^{-1}$ in the latter, perhaps due to application of large amounts of $\mathrm{P}$ fertilizers in the greenhouses. The distribution of available $\mathrm{P}$ in the soil profile in two cropping systems showed similar trends and decreased with depth. Soil available $P$ averaged over the 30 greenhouses $(0-30 \mathrm{~cm})$ was above the local recommended sufficiency level $\left(>150 \mathrm{mg} \mathrm{kg}^{-1}\right)$ and was at the moderate level $\left(14-30 \mathrm{mg} \mathrm{kg}^{-1}\right)$ in the cereal fields.

Soil available K $(0-90 \mathrm{~cm})$ in the greenhouses was also significantly $(p<0.001)$ higher than in the cereal fields (Fig. 2B), with $1817 \mathrm{~kg} \mathrm{~K} \mathrm{ha}^{-1}$ in the former and $811 \mathrm{~kg}$ $\mathrm{K} \mathrm{ha}^{-1}$ in the latter. Soil available $\mathrm{K}$ in the greenhouses decreased with increasing soil depth, but was similar throughout the soil profile in the cereal fields. Soil available K on average in the 30 greenhouses at $0-30 \mathrm{~cm}$ depth was at moderate level (150-200 mg kg${ }^{-1}$ ) and was much lower than the recommended sufficiency level $\left(>100 \mathrm{mg} \mathrm{kg}^{-1}\right)$ for wheat - maize fields. The substantial accumulation of $\mathrm{P}$ and $\mathrm{K}$ in the deep subsoil

Table 2

Average annual nutrient balance in the two cropping systems $\left(\mathrm{kg} \mathrm{ha}^{-1} \mathrm{year}^{-1}\right)$

\begin{tabular}{|c|c|c|c|c|c|c|}
\hline \multirow[t]{2}{*}{ Component } & \multicolumn{3}{|c|}{ Greenhouse vegetables } & \multicolumn{3}{|c|}{ Wheat-maize rotation } \\
\hline & $\mathrm{N}$ & $\mathrm{P}$ & $\mathrm{K}$ & $\mathrm{N}$ & $\mathrm{P}$ & K \\
\hline Nutrient (fertilizer + manure) input & $4670 \mathrm{a}^{\mathrm{a}}$ & $1409 \mathrm{a}$ & $1916 \mathrm{a}$ & $662 b$ & $110 \mathrm{~b}$ & $103 b$ \\
\hline Aboveground nutrient removal & $342 \mathrm{a}$ & $72 \mathrm{a}$ & $450 \mathrm{a}$ & $316 a$ & $45 b$ & $266 b$ \\
\hline Nutrient surplus & $4328 \mathrm{a}$ & $1337 \mathrm{a}$ & $1466 \mathrm{a}$ & $346 b$ & $65 b$ & $-163 b$ \\
\hline
\end{tabular}

${ }^{\text {a }}$ Mean values with the same letters for the same nutrient between two cropping systems are not significantly different at the 5\% level. 
Table 3

Comparison between the two cropping systems in soil OM and TN at $0-30 \mathrm{~cm}$ depth

\begin{tabular}{lllll}
\hline $\begin{array}{l}\text { Cropping } \\
\text { system }\end{array}$ & $\begin{array}{l}\text { No. of } \\
\text { sites }\end{array}$ & $\begin{array}{l}\text { Descriptive } \\
\text { statistics }\end{array}$ & $\begin{array}{l}\text { Soil OM } \\
\left(\mathrm{g} \mathrm{kg}^{-1}\right)\end{array}$ & $\begin{array}{l}\text { Soil TN } \\
\left(\mathrm{g} \mathrm{kg}^{-1}\right)\end{array}$ \\
\hline $\begin{array}{l}\text { Greenhouse } \\
\text { vegetables }\end{array}$ & \multirow{2}{*}{30} & Mean & 16.81 & 1.343 \\
& & Range & $10.50-24.02$ & $0.924-1.896$ \\
Wheat-maize & \multirow{2}{*}{30} & CV (\%) & 24.69 & 18.51 \\
rotation & & Mean & 13.17 & 0.965 \\
& & Range & $10.89-15.55$ & $0.825-1.274$ \\
Significance & & & 9.50 & 9.10
\end{tabular}

***Differences between the two systems in nutrient content are significant at $p<0.001$

reflects strong movement of $\mathrm{P}$ and $\mathrm{K}$ down the soil profile in the greenhouses resulting from large inputs of $\mathrm{P}$ and $\mathrm{K}$ fertilizers.

\subsection{Comparison between the two cropping systems in soil $\mathrm{pH}$ and $\mathrm{EC}$}

Soil $\mathrm{pH}$ in the top $90 \mathrm{~cm}$ of the soil profile was significantly $(p<0.001)$ lower in the greenhouses than the cereal fields (Fig. 3A). Soil pH was lower nearer the soil surface in the greenhouses, but averaged over 0-90 cm soil depth was similar in the cereal fields. Although soil $\mathrm{pH}$ in the top $30 \mathrm{~cm}$ in the greenhouses decreased by $0.52 \mathrm{pH}$ units compared with the cereal fields, the value remained high $(\mathrm{pH} 8)$. Soil $\mathrm{pH}$ decreased exponentially with $\mathrm{NO}_{3}^{-}-\mathrm{N}$ concentrations in all three soil layers (Fig. 4), which indicates that the substantial $\mathrm{NO}_{3}^{-}-\mathrm{N}$ accumulation was an important factor affecting soil acidification. This effect decreased with increasing soil depth as reflected by decreasing determining coefficient in the regression equation with increasing soil depth.

In contrast with soil $\mathrm{pH}$, soil EC values at $0-30$ and $30-60 \mathrm{~cm}$ depths in the greenhouses were significantly $(p<0.001)$ higher than in the cereal fields, while at $60-90 \mathrm{~cm}$ there was no significant $(p>0.05)$ difference (Fig. 3B). Soil EC was higher near the soil surface, indicating
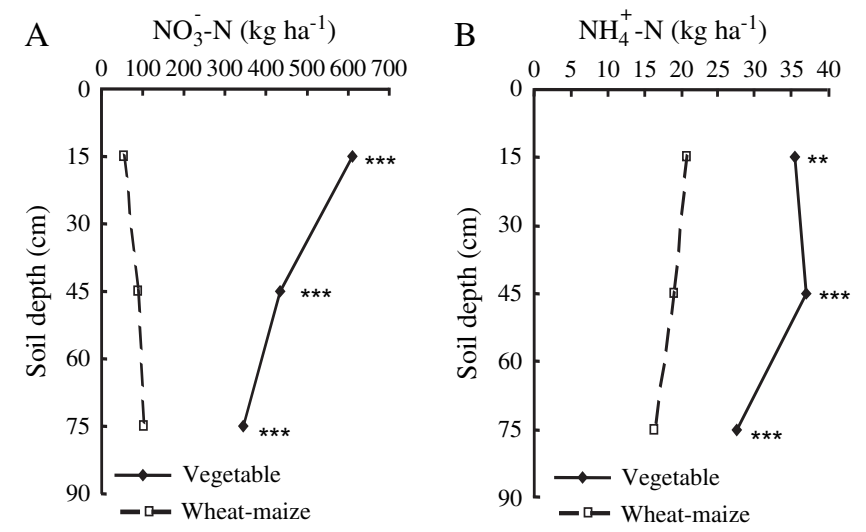

Fig. 1. Accumulation of $\mathrm{NO}_{3}^{-}-\mathrm{N}(\mathrm{A})$ and $\mathrm{NH}_{4}^{+}-\mathrm{N}$ (B) in soils in the two cropping systems $(* *, * * *$ indicate that differences between the two systems at the same soil depth are significant at $p<0.01$ and 0.001 , respectively). that the surface soil in the greenhouses readily accumulated salts. Soil EC vales were lower in the surface soils of the wheat - maize fields, and at $60-90 \mathrm{~cm}$ depth were not significantly $(p>0.05)$ different between the two cropping systems.

Soil EC values averaged over the top $90 \mathrm{~cm}$ of the soil profile were highly significantly and positively correlated with $\mathrm{NO}_{3}^{-}-\mathrm{N}$ concentrations (Fig. 5), indicating that the large amounts of $\mathrm{NO}_{3}^{-}-\mathrm{N}$ accumulated were an important factor contributing to soil salinity. The decrease in correlation coefficient with increasing soil depth indicates that soil EC was affected slightly by $\mathrm{NO}_{3}^{-}-\mathrm{N}$ accumulation in the deep subsoil. Variation in the nitrate concentrations at $0-30 \mathrm{~cm}$ soil depth explained $95 \%$ of the variance in soil EC.

\subsection{Comparison between the two cropping systems in trace elements and heavy metals}

The available $\mathrm{Fe}, \mathrm{Mn}, \mathrm{Cu}$, and $\mathrm{Zn}$ concentrations at $0-30 \mathrm{~cm}$ soil depth in the greenhouses were significantly $(p<0.01$ or 0.001$)$ higher than in the wheat-maize fields (Table 4), and were 1.2, 1.3, 1.3 and 1.4 times higher on average, perhaps reflecting the large application rates of fertilizers and manures in the greenhouses.

The soil $\mathrm{Pb}$ concentrations in the greenhouses were significantly $(p<0.05)$ lower than in the cereal fields (Table 4$)$, perhaps through reduced atmospheric inputs. However, soil $\mathrm{Cd}$ concentrations in the greenhouses were significantly $(p<0.001)$ higher than in the cereal fields (Table 4), perhaps due to large application rates of $\mathrm{P}$ fertilizers contaminated with $\mathrm{Cd}$. Soil $\mathrm{Cd}$ concentrations were significantly and positively correlated with soil Olsen P $\quad(y=0.0002 x+0.013$; $r=0.6424, p<0.01)$.

\section{Discussion}

Although our survey was a snapshot in time over a one-year period, a substantial quantity of detailed data were obtained on conventional agricultural practice in the management of the two cropping systems in northern China. We compared the fertilizer application rates in farming practice with the rates recommended by the local extension service. However, the mineral $\mathrm{N}$ fertilizer rate can be substantially reduced by use of the Nmin method both in greenhouse vegetables (He et al., 2006) and in wheat-maize rotations(Chen, 2003) because soils in conventional management practice have accumulated large amounts of Nmin as shown in this study. Thus, the Nmin method could be readily adopted by farmers to control $\mathrm{N}$ fertilizer inputs to minimize soil degradation and negative environmental impacts, especially in greenhouse vegetable production systems.

There were very large quantities of residual nutrients in the greenhouse soils after several years of high application rates of fertilizers and manures. Soil OM, TN, mineral N, available P and $\mathrm{K}$, available $\mathrm{Fe}, \mathrm{Mn}, \mathrm{Cu}, \mathrm{Zn}, \mathrm{Cd}$ and $\mathrm{EC}$ also increased while soil $\mathrm{pH}$ decreased. Excessive irrigation (usually $>1000 \mathrm{~mm}$ per crop, with two or three crops grown each year) led to leaching of $\mathrm{NO}_{3}^{-}-\mathrm{N}$ and $\mathrm{K}$ (Cameron et al., 

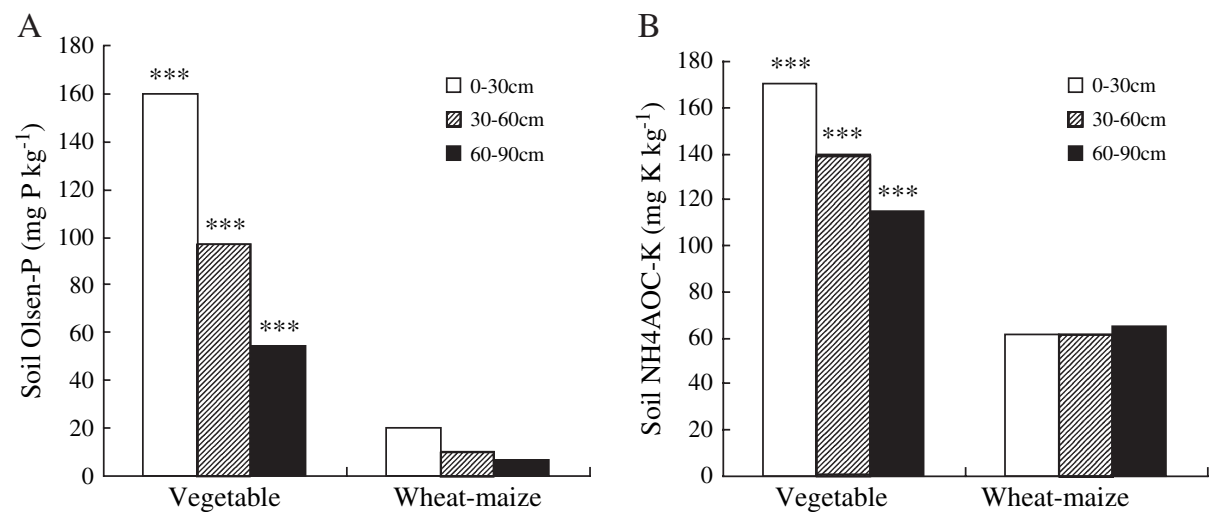

Fig. 2. Accumulation of $\mathrm{P}$ and $\mathrm{K}$ in soils of the two cropping systems (A: soil Olsen-P; $\mathrm{B}: \mathrm{NH}_{4} \mathrm{OAc}-\mathrm{K}$ ) (*** indicates that differences between the two systems in nutrient concentration at the same soil depth are significant at $p<0.001$ ).

1997; Li et al., 2001; Ju et al., 2004a; Zhu et al., 2005) and even some leaching of $\mathrm{P}$ to deeper soil layers. In fact, we measured nitrate concentrations in water leaching to a depth of $1.4 \mathrm{~m}$ in the soil profile of up to $120-210 \mathrm{mg} \mathrm{N} \mathrm{L}^{-1}$ after the tomato harvest during the survey year, a value much higher than the maximum permissible limit for drinking water $(20 \mathrm{mg}$ $\mathrm{NL}^{-1}$ ) in China. Some studies have shown over $228 \mathrm{~kg}$ $\mathrm{N} \mathrm{ha}^{-1}$ leached into groundwater in vegetable fields (Stites and Kraft, 2001; Kraft and Stites, 2003), resulting in nitrate concentrations in groundwater $3 \mathrm{~m}$ deep 20 times higher than in adjacent cereal fields upstream. High $\mathrm{N}$ application rates combined with high soil water contents also contributed significantly high $\mathrm{N}_{2} \mathrm{O}$ emission rates in greenhouse vegetable soils (He et al., 2006).

Numerous studies have shown that large amounts of accumulated nitrate in soils may also stimulate plants, especially leafy vegetables, to absorb and accumulate excessive nitrate (Petrovic et al., 1992; Santamaria et al., 1998; Wang et al., 2001). Humans consume the green soft parts of leaves and stems, and these are the plant parts that accumulate large amounts of nitrate (Walker, 1990). Nitrate accumulation in plants has been regarded as harmful to the human body and this has been of great concern to scientists and consumers (Rockman and Granli, 1991; L'hirondel and L'hirondel, 2002; Addiscott and Benjamin, 2004).

Studies at Rothamsted Research Station in SE England have shown a marked increase in $\mathrm{P}$ concentration in drainage water to more than $2 \mathrm{mg} \mathrm{L}^{-1}$ as soon as soil Olsen-P exceeded $60 \mathrm{mg} \mathrm{kg}^{-1}$ (Heckrath et al., 1995), while Olsen-P in our greenhouse vegetable soils reached $160 \mathrm{mg} \mathrm{P} \mathrm{kg}^{-1}$ on average at $0-30 \mathrm{~cm}$ depth, and $97 \mathrm{mg} \mathrm{P} \mathrm{kg}^{-1}$ at $30-60 \mathrm{~cm}$ depth in the present study. Large accumulation of $\mathrm{P}$ in soils may have significant effects on the surface- and groundwater environments and may merit further research in northeast China over the long term.

Concentrations of soil micronutrients increased significantly in greenhouses as a result of large inputs of manure and soil acidification. Soil available $\mathrm{Fe}, \mathrm{Mn}, \mathrm{Cu}$, and $\mathrm{Zn}$ at $0-30 \mathrm{~cm}$ depth in both cropping systems were at sufficiency levels (Fe: $>4.5 \mathrm{mg} \mathrm{kg}^{-1}$; Mn: $>5 \mathrm{mg} \mathrm{kg}{ }^{-1} ; \mathrm{Zn}:>0.5 \mathrm{mg}$ $\mathrm{kg}^{-1}$; $\mathrm{Cu}:>0.2 \mathrm{mg} \mathrm{kg}^{-1}$ ) (Hu and Zhou, 2003).

Soil Cd concentrations in greenhouses were 2.8 times those in wheat-maize fields on average. Fertilizers, manures and atmospheric deposition may be important sources of soil $\mathrm{Cd}$, which is slowly increasing in many agricultural soils (McLaughlin et al., 1999). The increase in soil Cd concentrations in this study may be mainly attributable to large application rates of manures and $\mathrm{P}$ fertilizers. This agrees with the conclusions of Williams and David (1976) who found that soil $\mathrm{Cd}$ concentrations $\left(0.008-0.028 \mathrm{mg} \mathrm{kg}^{-1}\right)$ and $\mathrm{Cd}$ in wheat grain $\left(0.03-0.06 \mathrm{mg} \mathrm{kg}^{-1}\right)$ were both positively correlated with application rate of $\mathrm{P}$ fertilizer $(0-60 \mathrm{~kg}$ $\mathrm{P} \mathrm{ha}^{-1}$ year $^{-1}$ ) after continual application of $\mathrm{P}$ fertilizer for five years. In the present study we found that of the $\mathrm{P}$
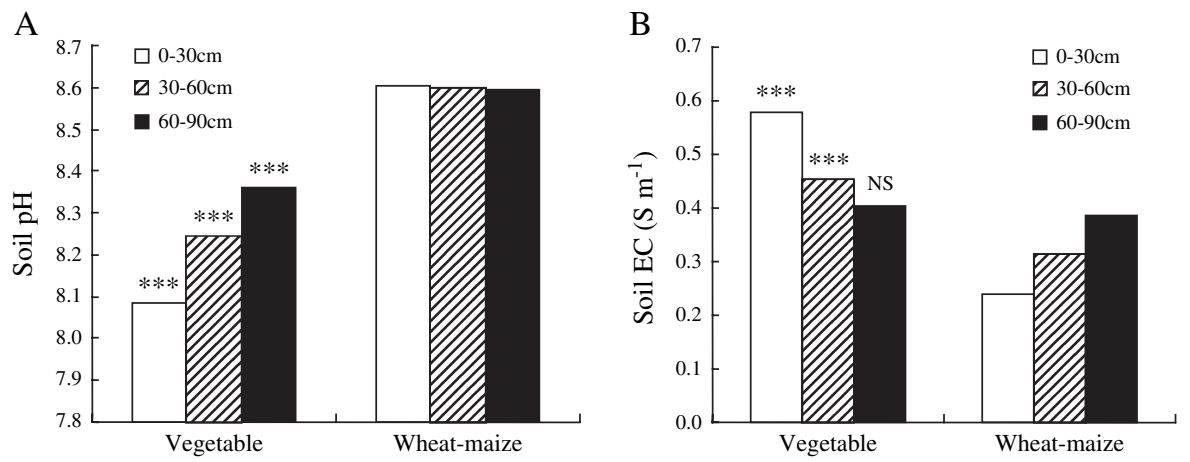

Fig. 3. Soil pH and electrical conductivity (EC) in the two cropping systems (A: soil pH; B: soil EC) (*** indicates that differences between the two systems in nutrient concentration at the same soil depth are significant at $p<0.001$; NS, no significant difference between the two systems at the same soil depth). 

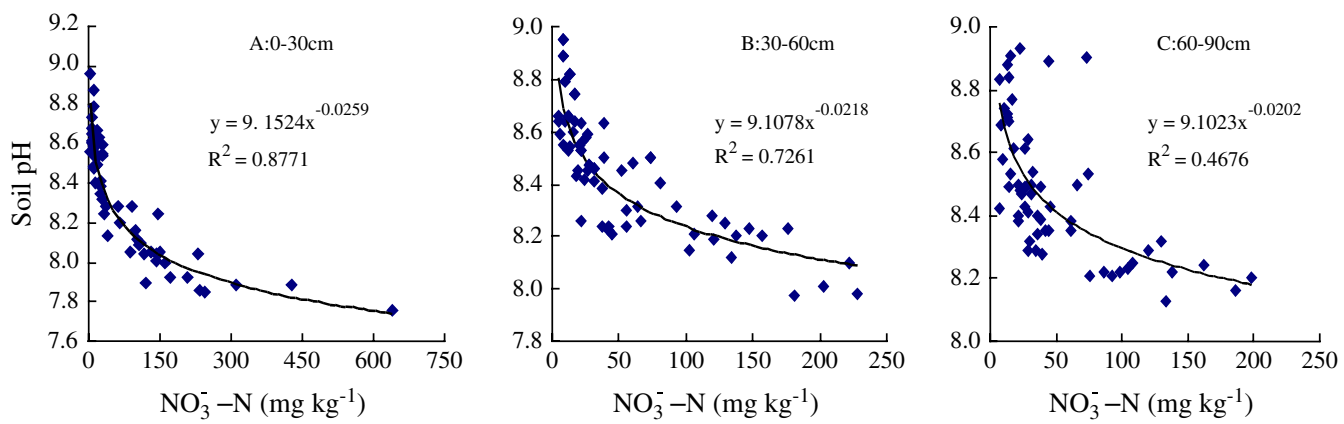

Fig. 4. Relationship between soil $\mathrm{pH}$ and soil $\mathrm{NO}_{3}^{-} \mathrm{N}$ concentration $(n=60)$.

fertilizers used in Huimin county, diammonium phosphate, usually imported from the U.S. or Morocco, amounted to more than $50 \%$ of those applied. Both sources are classified as high-Cd phosphate fertilizers with $\mathrm{Cd}$ concentrations of $8-105 \mathrm{mg} \mathrm{kg}^{-1}$ (U.S. source) and $9.4-22.9 \mathrm{mg} \mathrm{kg}^{-1}$ (Moroccan source) (Wang, 2002). Although soil Cd concentrations in greenhouses showed an increasing trend over time, the values were below $0.05 \mathrm{mg} \mathrm{kg}^{-1}$ on average, with the concentration in only four fields rising to $0.1 \mathrm{mg} \mathrm{kg}^{-1}$, far lower than the maximum permissible limit value $\left(0.3 \mathrm{mg} \mathrm{kg}^{-1}\right)$ and the warning value $\left(0.5 \mathrm{mg} \mathrm{kg}^{-1}\right)$ for agricultural soils in China (Wang and Wei, 1995).

In contrast with soil $\mathrm{Cd}$, soil $\mathrm{Pb}$ concentrations were slightly higher in wheat-maize fields than in the greenhouses on average. Atmospheric deposition and application of manures and sewage sludges are important sources of soil $\mathrm{Pb}$ in agricultural soils. Soil $\mathrm{Pb}$ in the study area may be derived mainly from atmospheric deposition because sewage sludge was not applied. Other studies have shown atmospheric deposition to be the most important source of soil $\mathrm{Pb}$ in most agricultural areas, representing $25-85 \%$ of total $\mathrm{Pb}$ inputs (Nicholson et al., 2003), and ranging from several grams to several hundred grams per hectare per year, with generally more than $30 \mathrm{~g} \mathrm{ha}^{-1}$ per year (Kockova et al., 1996; Nicholson et al., 2003). The soil $\mathrm{Pb}$ concentration was about $1 \mathrm{mg} \mathrm{kg}^{-1}$ in both cropping systems, a level unlikely to have any major effect on soil quality or the quality of agricultural products.

Soil $\mathrm{pH}$ at different soil depths in vegetable greenhouses was significantly lower than in wheat-maize fields and decreased exponentially with $\mathrm{NO}_{3}^{-}-\mathrm{N}$ concentrations at all three depth categories, indicating that nitrification processes after application of large amounts of $\mathrm{N}$ fertilizers may be a major factor leading to soil acidification. A soil $\mathrm{pH}$ decrease of 1.4 pH units was reported by Stamatiadis et al. (1999) in broccoli fields in the US due to surface application of ammonium nitrate that stimulated soil nitrification and acidification processes. Some published studies have shown a negative correlation between soil $\mathrm{pH}$ and $\mathrm{NO}_{3}^{-}-\mathrm{N}$ concentration in a similar fashion to our data (Patriquin et al., 1993). This correlation exists, however, only as long as lime is not regularly applied to maintain soil $\mathrm{pH}$ in the optimum range.

Another consequence of long-term high application rates of fertilizers in vegetable production was soil secondary salinization due to excessively high nutrient accumulation in soils. Soil EC can be used as an index of salinization. Most crops have a tolerance limit to EC of $0.4 \mathrm{~S} \mathrm{~m}^{-1}$ (Kingery et al., 1994). Soil EC at depths 0-30, 30-60, and $60-90 \mathrm{~cm}$ layers rose to $0.579,0.452$, and $0.403 \mathrm{~S} \mathrm{~m}^{-1}$ on average in the greenhouses, and these levels may have had some negative effects on crop growth. In the greenhouse vegetable production area farmers often abandon greenhouses older than 15 years because they are aware that damaging levels of soil salinization will have occurred. Soil EC in all three depth categories showed highly significant positive correlations with $\mathrm{NO}_{3}^{-}-\mathrm{N}$ concentrations, suggesting that substantial accumulation of $\mathrm{NO}_{3}^{-}-\mathrm{N}$ may have been an important factor contributing to soil salinity. This is in agreement with other studies (Patriquin et al., 1993; Smith and Doran, 1996). Some authors recommend using EC to estimate soil $\mathrm{NO}_{3}^{-}-\mathrm{N}$ concentration or as an index of soluble nutrients (Smith and Doran, 1996; Eigenberg et al., 2002) and even for monitoring soil $\mathrm{N}$ mineralization (De Neve et al., 2002).
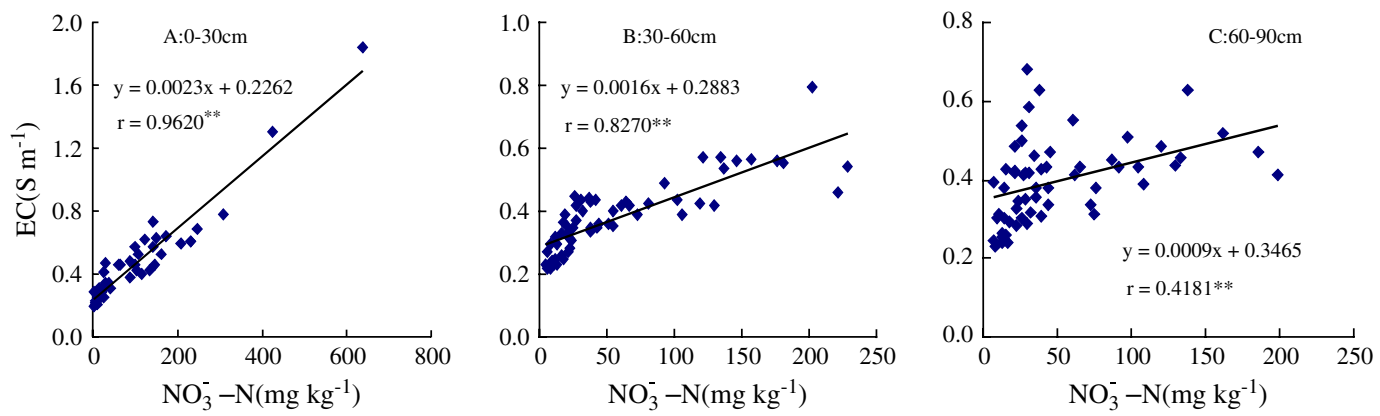

Fig. 5. Relationship between soil electrical conductivity (EC) and soil $\mathrm{NO}_{3}^{-} \mathrm{N}$ concentration $(n=60)$. 
Table 4

Concentrations of micronutrients and heavy metals at $0-30 \mathrm{~cm}$ soil depth in the two cropping systems

\begin{tabular}{|c|c|c|c|c|c|c|c|c|}
\hline \multirow[t]{2}{*}{ Cropping system } & \multirow{2}{*}{$\begin{array}{l}\text { No. of } \\
\text { fields }\end{array}$} & \multirow{2}{*}{$\begin{array}{l}\text { Descriptive } \\
\text { Statistics }\end{array}$} & \multicolumn{4}{|c|}{ Micronutrients $\left(\mathrm{mg} \mathrm{kg}^{-1}\right)$} & \multicolumn{2}{|c|}{ Heavy metal $\left(\mathrm{mg} \mathrm{kg}^{-1}\right)$} \\
\hline & & & $\mathrm{Fe}$ & $\mathrm{Mn}$ & $\mathrm{Zn}$ & $\mathrm{Cu}$ & $\mathrm{Pb}$ & $\mathrm{Cd}$ \\
\hline \multirow[t]{3}{*}{ Greenhouse vegetables } & \multirow[t]{3}{*}{30} & Mean & 13.67 & 14.84 & 3.67 & 2.25 & 0.98 & 0.048 \\
\hline & & Range & $7.76-24.80$ & $11.08-24.86$ & $1.30-7.37$ & $1.39-3.15$ & $0.79-1.24$ & $0.012-0.146$ \\
\hline & & $\mathrm{CV}(\%)$ & 28.28 & 22.48 & 47.42 & 20.70 & 11.52 & 66.41 \\
\hline \multirow[t]{3}{*}{ Wheat-maize rotation } & \multirow[t]{3}{*}{30} & Mean & 11.31 & 11.00 & 1.54 & 1.67 & 1.05 & 0.017 \\
\hline & & Range & $7.10-16.46$ & $8.72-13.84$ & $0.33-4.35$ & $1.35-2.57$ & $0.83-1.33$ & $0.010-0.056$ \\
\hline & & $\mathrm{CV}(\%)$ & 19.89 & 10.59 & 63.08 & 14.19 & 12.28 & 55.33 \\
\hline Significance & & & $* *$ & $* * *$ & $* * *$ & $* * *$ & $*$ & $* * *$ \\
\hline
\end{tabular}

$*$, **, ***Differences between the two systems in elemental concentration are significant at $p<0.05,0.01$ and 0.001, respectively.

However, this may be applicable only where nitrate is the main factor leading to salinization.

Farmers in Huimin County, Shandong province began to establish greenhouses in the 1980s and by 2002 the area under greenhouse vegetable production represented $19 \%$ of the total cultivated area. Soil OM, total N, and available $\mathrm{P}$ and $\mathrm{K}$ in the surface soils $(0-30 \mathrm{~cm})$ in greenhouses as measured in 2002 were $1.8,2.1,23.0$ and 1.3 times the values determined in the 1980s, while the corresponding data for wheat-maize fields were $1.4,1.5,2.9$ and 0.5 times compared to the 1980s (Anonymous, 1985). All the nutrients determined were found to have increased except for available $\mathrm{K}$ in wheat-maize fields. The accumulated nutrients show a clear tendency to move down to the deeper subsoil or shallow groundwater, and this may lead to serious environmental problems. Only the changes in soil chemical properties were investigated in the present study. It is likely that soil biological properties may also change dramatically after long-term high inputs of fertilizers and manures in greenhouse cultivation systems, and this requires further long-term investigation. Currently, farmers try to ignore these problems while pursuing maximum yields and high incomes (Zhu et al., 2005). Thus, further studies are needed to define accurately the nutrient inputs required for rational management of water and fertilizers in the quest for sustainable greenhouse vegetable production.

\section{Conclusions}

Rapid economic development and increasing living standards in China since the 1980s have encouraged the rapid development of vegetable production, especially greenhouse vegetable production, in north China and this has became one of most important economic activities in rural areas. Fertilizer and manure application rates in greenhouse vegetable production are often several times higher than recommended by the local extension service. This, combined with excessive irrigation, has led to substantial accumulation of soil nutrients such as $\mathrm{NO}_{3}^{-}-\mathrm{N}$, $\mathrm{P}$, and $\mathrm{K}$ with leaching to the shallow groundwater. Low fertilizer $\mathrm{N}$ efficiency, with crop recoveries of less than $10 \%$ of fertilizer $\mathrm{N}$ in most cases, also increases gaseous losses. This situation is so serious that the quality of soil, air and groundwater is deteriorating. Environmental protection and high crop yields could be achieved by avoiding the application of more nutrients than are actually removed from the field (providing the available nutrient levels are high enough to sustain high yields) and by basing $\mathrm{N}$ application on the amounts of Nmin plus the amount usually mineralized during the cropping season (different allowances being made according to the level of soil organic matter). China must formulate appropriate agricultural policies at a national level to enhance the extension services and educate farmers to reduce nutrient inputs for sustainable crop production.

\section{Acknowledgments}

We acknowledge generous financial support from the National Natural Science Foundation of China (Grant nos. 40571071, 30270787 and 30390081) and a Key Project of the 15th National Plan (Grant no. 2004BA516A01).

\section{References}

Addiscott, T.M., Benjamin, N., 2004. Nitrate and human health. Soil Use and Management 20, 1-12.

Anonymous, 1985. Soils in Huiming County, Shandong province. Office of the Second Soil Survey of Huiming County (in Chinese).

Cameron, K.C., Di, H.J., McLaren, R.G., 1997. Is soil an appropriate dumping ground for our wastes? Australian Journal of Soil Research 35, 995-1035.

Che, S., He, P.A., 1999. Manure analysis. In: Lu, R.K. (Ed.), Methods of Soil and Agricultural Chemistry Analysis. China Agricultural Science and Technology Publishers, Beijing, pp. 423-428.

Chen, X.P., 2003. Optimization of the $\mathrm{N}$ fertilizer management of a winter wheat/summer maize rotation system in the Northern China Plain. Ph. D. Dissertation, University of Hohenheim, Stuttgart, Germany.

De Neve, S., Van de Steene, J., Hartmann, R., Hofman, G., 2002. Using time domain reflectometry for monitoring mineralization of nitrogen from soil organic matter. European Journal of Soil Science 51, 295-304.

Doran, J.W., Sarrantonio, M., Liebig, M.A., 1996. Soil health and sustainability. Advances in Agronomy 56, 1-54.

Dou, L.F., 2005. The nitrogen fertilizer use efficiency and soil quality variation of vegetable soil systems in the Yangtze delta area. Ph D thesis, Chinese Academy of Agricultural Sciences, Beijing, China (in Chinese with English summary).

Eigenberg, R.A., Doran, J.W., Nienaber, J.A., Ferguson, R.B., Woodbury, B.L., 2002. Electrical conductivity monitoring of soil condition and available $\mathrm{N}$ with animal manure and a cover crop. Agriculture, Ecosystems and Environment 88, 183-193.

Gao, B.M., Yu, S.F., Gao, X.B., Zhang, Y.L., Li, G.S., 2000. Investigation on soil nutrient and salt contents in winter plastic covered sheds in Shandong province. In: Li, X.L., Zhang, F.S., Mi, G.H. (Eds.), Fertilizing for Sustainable Production of High Quality Vegetables. China Agricultural University Publisher, Beijing, pp. 48-51 (in Chinese with English abstract). 
Greenway, H., Munns, R., 1980. Mechanisms of salt tolerance in non-halophytes. Annual Review of Plant Physiology and Plant Molecular Biology 31, 149-190.

He, Q.W., Chen, Y.Q., Jiao, Z.G., 2000. Production techniques of protected vegetable systems. Shandong Agricultural Science 6, 13-15 (in Chinese).

He, F.F., Chen, Q., Jiang, R.F., Chen, X.P., Zhang, F.S., 2006. Yield and nitrogen balance of greenhouse (Lycopersicum esculentum Mill.) with conventional and site-specific nitrogen management in Northern China. Nutrient Cycling in Agroecosystems, doi:10.1007/s10705-006-6275-7.

Heckrath, G., Brookes, P.C., Poulton, P.R., Goulding, K.W.T., 1995. Phosphorus leaching from soils containing different phosphorus concentrations in the Broadbalk experiment. Journal of Environmental Quality 24, 904-910.

Hu, G.T., Zhou, L.X., 2003. Plant nutrition. China Agricultural University Publisher, Beijing (in Chinese)86-135.

Jin, X.C., Xu, Q.J., Huang, C.Z., 2005. Current status and future tendency of lake eutrophication in China. Science in China Ser. C Life Sciences 48 (Special issue), 948-954.

Jinadasa, K.B.P.N., Milham, P.J., Hawkins, C.A., Cornish, P.S., Williams, P.A., Kaldor, C.J., Conroy, J.P., 1997. Survey of cadmium levels in vegetables and soils of greater Sydney, Australia. Journal of Environmental Quality 26, 924-933.

Ju, X.T., Liu, X.J., Zhang, F.S., Roelcke, M., 2004a. Nitrogen fertilization, soil nitrate accumulation, and policy recommendations in several agricultural regions of China. Ambio 33, 300-305.

Ju, X.T., Liu, X.J., Zhang, F.S., 2004b. Nitrogen transformations in a Chinese Aquic Cambisol applied urea with dicyandiamide or plant residues. Communications in Soil Science and Plant Analysis 35, 2397-2416.

Ju, X.T., Wan, Y.J., Kou, C.L., Zhang, F.S., 2005. Nitrate accumulation in agricultural soils and groundwater of the North China Plain. In: Li (Ed.), Plant Nutrition for Food Security, Human Health and Environmental Protection. Tsinghua University Press, Beijing, pp. 1056-1057.

Kingery, W.L., Wood, C.W., Delaney, D.P., Williams, J.C., Mullins, G.L., 1994. Impact of long-term land application of broiler litter on environmentally related soil properties. Journal of Environmental Quality 23, 139-147.

Kockova, E., Palat, M., Betusova, M., 1996. Bioelements and heavy metals in dry and wet depositions at some localities in the Morava River basin. Water Science and Technology 33, 277-283.

Kraft, G.J., Stites, W., 2003. Nitrate impacts on groundwater from irrigatedvegetable systems in a humid north-central US sand plain. Agriculture, Ecosystems and Environment 100, 63-74.

L'hirondel, J., L'hirondel, J.L., 2002. Nitrate and Man: Toxic, Harmless or Beneficial? CAB International, Wallingford, Oxon, UK.

Li, J.L., 2001. Study on fertilization of vegetables with two different cultivated models in Laiyang and Shouguang, Shandong province. $\mathrm{Ph} \mathrm{D}$ Thesis, China Agricultural University, Beijing, China (in Chinese with English summary).

Li, J.L., Zhu, J.H., Zhang, X.S., Meng, X.X., Chen, Q., Li, X.L., Zhang, F.S., 2001. Nitrate leaching loss from soil and nutrient utilization by tomato in protected field. Chinese Journal of Applied Environmental Biology 7, 126-129 (in Chinese with English abstract).

Liang, C.H., Tang, Y., Xu, X.C., Hui, C.Z., 1997. Dynamics of soil salt in protected vegetable fields in Shenyang, China. In: Xie, J.C., Chen, D.X. (Eds.), Soil Fertility and Fertilizer Recommendation in Vegetable Fields. Hehai University Publisher, Nanjing, pp. 283-288 (in Chinese with English abstract).

Liu, X.J., Ju, X.T., Zhang, F.S., Pan, J.R., Christie, P., 2003. Nitrogen dynamics and budgets in a winter wheat-maize cropping system in the North China Plain. Field Crops Research 83, 111-124.

McLaughlin, M.J., Parker, D.R., Clarke, J.M., 1999. Metals and micronutrients - food safety issues. Field Crops Research 60, 143-163.

Meng, H.G., Li, Z., Liu, Y.J., 2000. Characteristics of the physical and chemical properties in the protected vegetable soils. Bulletin of Chinese Soil Science 31, 70-72 (in Chinese with English abstract).

Nicholson, F.A., Smith, S.R., Alloway, B.J., Carlton-Smith, C., Chambers, B.J., 2003. An inventory of heavy metals inputs to agricultural soils in England and Wales. Science of the Total Environment 311, 205-219.
Patriquin, D.G., Blaikie, H., Patriquin, M.J., Yang, C.Z., 1993. On-farm measurements of $\mathrm{pH}$, electrical conductivity and nitrate in soil extracts for monitoring coupling and decoupling of nutrient cycles. Biological Agriculture and Horticulture 9, 231-272.

Petrovic, N., Kastori, R., Scaife, A., 1992. Production of leafy vegetable with low concentration of nitrate, in: Proceedings 2nd Conference Of the European Society for Agronomy, Warwick University, pp. 422-432.

Powlson, D.S., 1997. Integrating agricultural nutrient management with environmental objective: Current state and future prospects. The Fertilizer Society, Proceedings, No. 402.

Rhoades, J.D., 1996. Salinity: Electrical conductivity and total dissolved solids. In: Sparks, D.L. (Ed.), Methods of Soil Analysis. Part 3. Chemical Methods. SSSA Book Series: No.5. SSSA and ASA, Madison, WI, pp. 417-435.

Richter, J., Roelcke, M., 2000. The N-cycle as determined by intensive agriculture: examples from central Europe and China. Nutrient Cycling in Agroecosystems 57, 33-46.

Rockman, O.C., Granli, T., 1991. Human health aspects of nitrate intake from food and water. In: Mervysn, L.R. (Ed.), Chemistry of Agriculture and Environment. The Royal Society of Chemistry, pp. 373-388.

Santamaria, P., Elia, A., Parente, A., Serio, F., 1998. Fertilization strategies for lowering nitrate accumulation in leafy vegetables: Chicory and rocket salad case. Journal of Plant Nutrition 21, 1791-1803.

Sharpley, A.N., Menzel, R.G., 1987. The impact of soil and fertilizer phosphorus on the environment. Advances in Agronomy 41, 297-324.

Smith, J.L., Doran, J.W., 1996. Measurement and use of $\mathrm{pH}$ and electrical conductivity for soil quality analysis. In: Doran, J.W., Jones, A.J. (Eds.), Methods for Assessing Soil Quality, Soil Science Society of American. Special Publication 49. SSSA, Madison, WI.

Song, F., Guo, Y.W., Liu, X.Y., 1996. Composite contamination of Cd, Zn and $\mathrm{Pb}$ in soils. Chinese Journal of Environmental Science 16, 431-436 (in Chinese with English abstract).

Stamatiadis, S., Werner, M., Buchanan, M., 1999. Field assessment of soil quality as affected by compost and fertilizer application in a broccoli field (San Benito County, California). Applied Soil Ecology 12, 217-225.

Stites, W., Kraft, G.J., 2001. Nitrate and chloride loading to groundwater from an irrigated north-central U.S. sand plain vegetable field. Journal of Environment Quality 30, 1176-1184.

Van Eerdt, M., van Grinsven, H., Willems, J., Schotten, K., 2005. A review of Dutch manure and fertilizer policy. In: Zhu, Z.L., Minami, K., Xing, G.X. (Eds.), Proceedings of the 3rd International Nitrogen Conference. Science Press, Beijing/Science Press, USA, pp. 339-347.

Walker, R., 1990. Nitrate, nitrite and N-nitroso compounds: A review of the occurrence in food and diet and the toxicological implications. Food Additives and Contaminants 7, 717-768.

Wang, J.P., 2002. Cd problems in high concentration P fertilizers after China entrance WTO. Phosphorus and Compound Fertilizer 17, 11-15 (in Chinese).

Wang, Y., Wei, F.S., 1995. Soil Environmental Chemistry. Chinese Environmental Science Publishing House, Beijing.

Wang, Z.H., Tian, X.H., Li, S.X., 2001. The cause of nitrate accumulation in leafy vegetables. Acta Ecologica Sinica 21, 1136-1141 (in Chinese with English abstract).

Williams, C.H., David, D.J., 1976. The accumulation of cadmium residues from phosphate fertilizers and their effect on the content of plants. Soil Science 121, 86-93.

Wu, F.Z., Zhao, F.Y., Liu, Y.Y., 2000. Analysis of the problems in continues cropping system of protective vegetable and the controlling ways. In: Li, X.L., Zhang, F.S., Mi, G.H. (Eds.), Fertilizing for Sustainable Production of High Quality Vegetables. China Agricultural University Publisher, Beijing, pp. 157-163 (in Chinese with English abstract).

Xiao, Q.M., Gao, X.L., Lu, C.Y., 1997. Current status of soil fertility in protected vegetable fields in Liaoning province. In: Xie, J.C., Chen, D.X. (Eds.), Soil Fertility and Fertilizer Recommendation in Vegetable Fields. Hehai University Publisher, Nanjing, pp. 52-56 (in Chinese with English abstract).

Xue, J.C., Bi, D.Y., Li, J.J., Yin, Y.X., Wu, Z.H., 1994. The physiological problems caused by soil factors in protected vegetable fields. Soil and Fertilizer 1, 4-9 (in Chinese with English abstract). 
Zhang, W.L., Tian, Z.X., Zhang, N., Li, X.Q., 1996. Nitrate pollution of groundwater in northern China. Agriculture. Ecosystems and Environment $59,223-231$.

Zhang, W.L., Wu, S.X., Ji, H.J., Kolbe, 2004. The current situation and controlling measures of non-point source pollutions in China. Scientia Agricultura Sinica 37, 1008-1017 (in Chinese with English abstract).
Zhao, F.Y., Wu, F.Z., Liu, D., 2000. Studies on the physical and chemical properties of the protected vegetable soils. Soil and Fertilizer 2, 11-13 (in Chinese with English abstract).

Zhu, J.H., Li, X.L., Christie, P., Li, J.L., 2005. Environmental implications of low nitrogen use efficiency in excessively fertilized hot pepper (Capsicum frutescens L.) cropping systems. Agriculture. Ecosystems and Environment $111,70-80$ 